\title{
Study of Multi-Model Ensemble High-Resolution Projections of Major Climatic Variables Over the Indus River Basin and Pakistan
}

\author{
Ghulam Hussain Darsi ${ }^{1 a}$, Mehran Sattar ${ }^{1 b}$, Muhammad Touseef ${ }^{2}$, Courtenay Strong ${ }^{3}$, \\ Muhammad Raza Najafi ${ }^{4}$
}

RECEIVED ON 13.11.2019, ACCEPTED ON 19.05.2020

\begin{abstract}
Water resources managers and policy-makers need reliable projections of hydro-climatic conditions to develop sound water management policies. Global Climate Models (GCMs) are the primary basis for projecting how the climate may change over the coming decades. However, GCMs have low spatial resolution and inherent biases that limit their direct utility for understanding localized climate change impacts. These limitations are particularly pronounced in mountainous areas, where the terrain exhibits variations at scales much finer than the GCM grid spacing. The main goal of this study is to downscale precipitation and mean temperature simulations from an ensemble of 10 GCMs that participated in the Coupled Model Intercomparison Project Phase-5 (CMIP5) under two Representative Concentration Pathways - RCP4.5 and RCP8.5. The simulations were bias corrected using quantile mapping and downscaled to a 30 arc second spatial resolution (approximately $1 \mathrm{~km}$ ) through using the delta method over the Indus River Basin and Pakistan for 2040-2070. The GCM processing was carried out using the Global Climate Data (GCD) package. The results show that for all seasons and most of the Indus River Basin (IRB) and Pakistan, future precipitation will be highly uncertain except UIB wherein mean annual precipitation is projected to increase by $8 \%$ under RCP 4.5 and $14 \%$ under RCP 8.5. However, the models are highly confident about increase in the temperature for this region. Relative to the baseline period (1960-1990), the annual mean temperature in the IRB is projected to increase by $2^{\circ} \mathrm{C}$ under RCP 4.5 and $2.6^{\circ} \mathrm{C}$ under RCP 8.5 for 2040-2070.
\end{abstract}

Keywords: Climate Change, Statistical Downscaling, Bias Correction, Indus River Basin, Pakistan.

\section{INTRODUCTION}

$\mathrm{T}$ The Indus River is often referred to as a "lifeblood" of Pakistan because it provides water for the country's irrigation system, which is one of the world's largest irrigation systems.
Pakistan is one of the most vulnerable countries to the adverse impacts of climate change. According to the Global Climate Risk Index (CRI) 2018 [1], Pakistan has been ranked at the seventh in the list of most affected countries. The CRI 2018 categorizes the countries accounting the recent impacts of extreme

${ }^{1}$ U.S.-Pakistan Center for Advanced Studies in Water (USPCAS-W), Mehran University of Engineering and Technology, Jamshoro, Sindh, Pakistan.

Email: aghdars.uspcasw@ faculty.muet.edu.pk (Corresponding Author), ${ }^{\mathrm{b}}$ mehran4015@ gmail.com

${ }^{2}$ College of Civil Engineering and Architecture, Guangxi University, Nanning, China.

Email: engrtouseef3347@gmail.com

${ }^{3}$ Department of Atmospheric Sciences, University of Utah, Salt Lake City, Utah, USA.

Email: court.strong@utah.edu

${ }^{4}$ Department of Civil and Environmental Engineering, Western University, London, Ontario, Canada. Email:mnajafi7@uwo.ca

This is an open access article published by Mehran University of Engineering and Technology, Jamshoro under CC BY 4.0 International License. 
weather events such as storms, floods, heat waves, etc. and related socio-economic data based on the period 1997 to 2016. The country is facing various climaterelated challenges, of which changes in precipitation and temperature are significantly important in the climatic water balance [2, 3]. Rising temperature is one of the most serious concerns which could influence the hydrological cycle, deteriorating critical water conditions and impacting almost every sector of life. In the past five decades, the mean annual temperature in Pakistan has raised to approximately $0.5^{\circ} \mathrm{C}[4]$. According to the Inter-Governmental Panel on Climate Change Assessment Report 5 (IPCC AR5), climate models project that the global temperature is likely to increase from $0.3^{\circ} \mathrm{C}$ to $1.7^{\circ} \mathrm{C}$ under the lowest emission scenarios; whereas, it is likely to rise from $2.6^{\circ} \mathrm{C}$ to $4.8^{\circ} \mathrm{C}$ for the higher emission scenarios over this region. Moreover, precipitation in Pakistan has increased significantly over the past century, but future changes in precipitation patterns are not well understood [5].

The GCMs are the best available tools to simulate climate change. However, their low spatial resolution renders them unable to resolve the impacts of most fine-scale topographic features. Downscaling is the process of refining the model spatial resolution so that it is suitable for evaluating local conditions [6]. There are two categories of downscaling methods: statistical and dynamical. In dynamical downscaling, regional climate models are nested within boundary conditions provided by the GCMs. In contrast, statistical downscaling applies robust empirical relationships between local factors and large-scale climate predictors. An advantage of statistical downscaling methods is that they are computationally efficient and easier to configure across multiple geographical regions.

Several studies have downscaled precipitation and temperature over the Indus River Basin and Pakistan. Amin et al. [7] have applied SimCLIM model to compute the projected changes over Southern Punjab under three Representative Concentration Pathways (RCP4.5, RCP6.0 and RCP8.5) for two years (2025 and 2050). They found that precipitation projected by ensemble models is highly uncertain while temperature is projected to increase in this region at the $95 \%$ confidence level. Saeed and Athar [8] have analyzed 22 raw GCMs for precipitation and temperature projections over Pakistan region for three future time periods (2025-2049, 2050-2074, and 20752099) under three greenhouse gas scenarios from the Special Report on Emission Scenarios (A2, A1B, and B1). They showed that both temperature and precipitation are projected to increase, and they also showed that precipitation projections are uncertain for the winter season. In addition, Su et al. [9] statistically downscaled $21 \mathrm{GCMs}$ to $0.5^{\circ}$ resolution for the IRB under three RCP scenarios for monthly precipitation and temperature, and found that both are projected to increase in the future. Kazmi et al. [10] employed the Statistical Down Scaling Model (SDSM) to downscale daily minimum and maximum temperature data of 44 gauge stations based on A2 and B2 scenarios. They found out that temperature would be increasing with larger changes in the UIB. Likewise, Mahmood and Babel [11] applied SDSM tool to downscale maximum temperature, minimum temperature and precipitation in the upper Jhelum River basin under A2 and B2 scenarios, and they found significant increases in all three variables in the future. A study conducted by Farooqi et al. [12] assessed projected changes in Pakistan for the second half of the current century and they found that spatially averaged precipitation will decrease in the future over most of Pakistan, with slight increases over northern parts. These studies have been conducted either on the small spatial scale [7] or used older data such as CMIP3 [8, 11, 12]. Some of the studies, such as Su et al. [9] and Kazmi et al. [10], focused on downscaling the whole Indus Basin and Pakistan respectively, but their resolution is too coarse for use in hydrological studies or crop water modeling. In addition, consideration of uncertainty is critical for policymakers and water managers to ensure they understand the confidence of the information that they are using in their decision making processes.

This study examines projected changes in 31-year mean precipitation and temperature by bias correcting and downscaling monthly output of 10 CMIP5 models over the IRB and Pakistan under the two scenarios RCP 4.5 and RCP 8.5. The selection of 10 GCMs was totally random as we could not find any study describing the performance of the model over this region. The monthly GCM simulations are processed 
by bias correcting them with quantile mapping and downscaling them to 30 arc seconds (approximately 1 $\mathrm{km}$ ) with the delta method using the Global Climate Data (GCD) package [13]. The study also examines the uncertainty in these projections, providing critical insights on the confidence of projections. Due to computational resource limitations, we processed only 10 GCMs. In the case of the IRB and Pakistan, obtaining high-resolution downscaled data for research is quite challenging. To bridge this gap, the high resolution downscaled data will be freely available at http://ccipp.water.muet.edu.pk/ so that research in the field of climate impacts assessment may be advanced for this region.

\section{MATERIALS AND METHODS}

\subsection{Study Area}

The spatial extent of this study region is the Indus River Basin (IRB) and Pakistan (Fig.1). IRB is a transboundary river basin covering an area of 1.12 million square $\mathrm{km}$, which is distributed between four countries - Pakistan (47\%), India (39\%), China (8\%), and Afghanistan (6\%) [14]. The IRB stretches from the Himalayan-Karakoram-Hindu Kush (HKHK) mountain headwaters to the low-lying plains of Sindh Province [15]. While the Indus River delivers large volumes of precious water, much of the IRB is relatively arid to semi-arid. Annual precipitation varies from 1500 to $2000 \mathrm{~mm}$ in the UIB and 100 to $500 \mathrm{~mm}$ in the lower Indus basin [14]. The complex topography has a major influence on the variation of average temperatures in the basin - the northern region has the lowest temperature while the southern region has higher temperatures. Mean temperatures are as high as $15^{\circ} \mathrm{C}$ during summer in the north, whereas, they reach up to $35^{\circ} \mathrm{C}$ in the south. The mean winter temperature is below zero in the northern parts and ranges $20-25^{\circ} \mathrm{C}$ in southern parts [4].

\subsection{Datasets}

Five gridded climate data sets were used in this study including the monthly time series of low-resolution CMIP5 GCM simulations, $0.5^{\circ}$ resolution Global Precipitation Climatology Center (GPCC) observed gridded data [16], $0.5^{\circ}$ resolution CRU observed gridded temperature data [17], Global Historical Climatology Network (GHCN) station records [18, 19] and the 30-arc second Worldclim climatology dataset [20].

An ensemble of $10 \mathrm{GCMs}$ (Table 1) that participated in the Coupled Model Intercomparison Project Phase-5 (CMIP5) [21] is used in this study. As noted in the Introduction, we limited the analysis to a 10GCM subset of the ensemble due to computational resources. The CMIP5 uses four Representative Concentration Pathways (RCPs) - named as RCP 2.6, RCP 4.5, RCP 6.0, and RCP 8.5. These scenarios are used to project how the climate may change in the future based on different amounts of radiative forcing. These labels indicate the approximate greenhouse gas radiative forcing at the end of the 21st century relative to preindustrial. The CMIP5 GCM simulations used in this study are obtained from the Earth Science Grid Federation archive data portal (http://esgf.llnl.gov). Thirty-one years of monthly model output have been selected for the historical baseline (1960-1990) and the future period (2040-2070). For individual GCMs providing multiple simulations for a given RCP, we analyzed only the first such member ("r1ilp1").

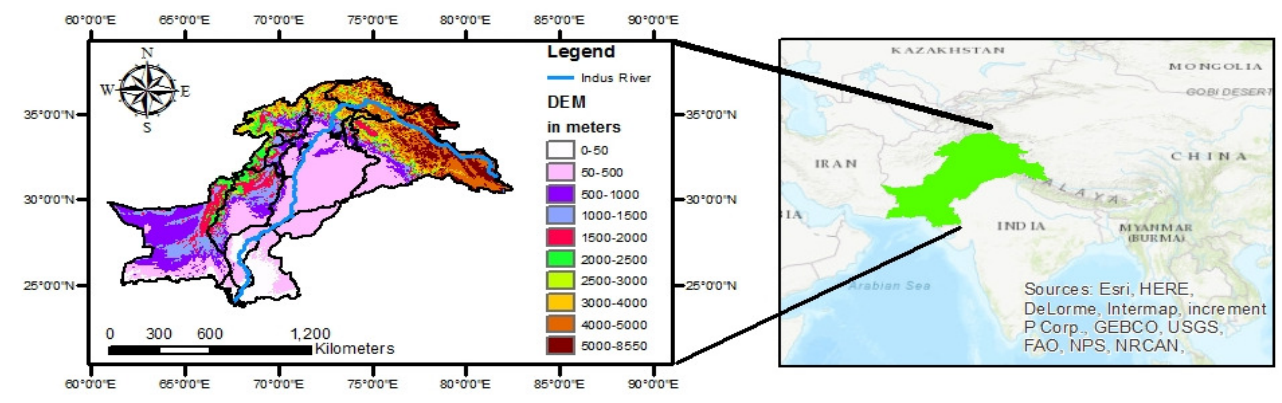

Fig. 1: Map of the Indus River Basin and Pakistan 


\begin{tabular}{|c|c|c|c|c|c|}
\hline \multicolumn{6}{|c|}{ Table 1: CMIP5 Models Used in this Study } \\
\hline S. No. & Model ID & Institution & Country & $\begin{array}{l}\text { Resolution } \\
\text { (Lon x Lat) }\end{array}$ & Reference \\
\hline 1. & CCSM4 & $\begin{array}{l}\text { US National Center for } \\
\text { Atmospheric Research }\end{array}$ & United States & $1.25^{\circ} \times 0.95^{\circ}$ & {$[22]$} \\
\hline 2. & CESM1-BGC & Community Earth System Model & United States & $1.25^{\circ} \times 0.95^{\circ}$ & {$[23]$} \\
\hline 3. & MIROC5 & $\begin{array}{l}\text { University of Tokyo, National } \\
\text { Institute for Environmental } \\
\text { Studies, and Japan for Marine- } \\
\text { Earth Science and Technology }\end{array}$ & Japan & $1.406^{\circ} \times 1.406^{\circ}$ & {$[24]$} \\
\hline 4. & ACCESS1-3 & $\begin{array}{l}\text { Commonwealth Scientific and } \\
\text { Industrial Research Organization } \\
\text { and Bureau of Meteorology }\end{array}$ & Australia & $1.875^{\circ} \times 1.25^{\circ}$ & {$[25]$} \\
\hline 5. & INM-CM4 & $\begin{array}{c}\text { Russian Institute for Numerical } \\
\text { Mathematics (INM) }\end{array}$ & Russia & $2.0^{\circ} \times 1.5^{\circ}$ & {$[26]$} \\
\hline 6. & CSIRO-Mk3-6-0 & $\begin{array}{l}\text { Queensland Climate Change } \\
\text { Center of Excellence and } \\
\text { Commonwealth Scientific and } \\
\text { Industrial Research Organization }\end{array}$ & Australia & $1.875^{\circ} \times 1.875^{\circ}$ & [27] \\
\hline 7. & MPI-ESM-LR & $\begin{array}{c}\text { Max-Planck_Institut fur } \\
\text { Meteologie }\end{array}$ & Germany & $1.875^{\circ} \times 1.875^{\circ}$ & {$[28]$} \\
\hline 8. & GFDL-CM3 & $\begin{array}{l}\text { NOAA Geophysical Fluid } \\
\text { Dynamics Laboratory }\end{array}$ & United States & $2.5^{\circ} \times 2.0^{\circ}$ & [29] \\
\hline 9. & BCC-CSM1-1 & $\begin{array}{l}\text { Beijing Climate Center, China } \\
\text { Meteorological Administration }\end{array}$ & China & $2.8^{\circ} \times 2.8^{\circ}$ & {$[30]$} \\
\hline 10. & CanESM2 & $\begin{array}{c}\text { Canadian Center for Climate } \\
\text { Modeling and Analysis }\end{array}$ & Canada & $2.8^{\circ} \times 2.8^{\circ}$ & {$[31]$} \\
\hline
\end{tabular}

\subsection{Methodology}

The monthly GCM simulations were processed by bias correcting them with quantile mapping and downscaling them to 30 arc seconds (approximately 1 $\mathrm{km}$ ) with the delta method. The downscaling procedure used two sets of historical gridded observations: $0.5^{\circ}$ resolution precipitation from the Global Precipitation Climatology Center (GPCC), and $0.5^{\circ}$ resolution air temperatures from the Climate Research Unit (CRU) TS 3.23 dataset. The research shows that the GPCC data is considered to be "state of the art" and compares favorably with other observational precipitation datasets [32].

\subsubsection{Quantile Mapping}

In this method, bias correction is performed by empirical quantile mapping [13, 33, 34] which is a univariate bias correction technique. In this method, empirical CDFs (ecdf) are calculated for each GCM and observed gridded datasets. Mathematically, it can be represented as in equation (1).

$P(Y)=\operatorname{ecdf}_{\text {mod,proj }}[\mathrm{Y}]$

where, ecdf refers to the function which gives the non- exceedance probability, mod refers to modeled, and proj refers to projection simulation. Then, climate values of the variable ' $\mathrm{Y}$ ' corresponding to the given non-exceedance probability can be estimated by the formula given in equation (2). Here ' $\mathrm{Y}$ ' may be any climatic variable i.e. precipitation or temperature.

$\mathrm{Y}=\operatorname{ecdf}^{-1}[\mathrm{P}(\mathrm{Y})]$

The bias correction can be done by developing transfer factors (TF) between observed gridded data and GCM simulation data over a similar historical period for all $\mathrm{P}$ in the CDF. It can mathematically be described by the following equations:

$$
\mathrm{TF}[\mathrm{P}]=\operatorname{ecdf}^{-1} \text { obs,hist }[\mathrm{P}]-\operatorname{ecdf}^{-1} \text { mod,hist }[\mathrm{P}]
$$

where obs, hist refers to the historic observed data and mod, hist refers to the historic modeled data (GCM historic simulations). Then, bias corrected value can be represented by

$\mathrm{Y}^{\prime}=\mathrm{Y}+\mathrm{TF}[\mathrm{P}(\mathrm{Y})]$

The transfer functions are applied to future GCM simulations for downscaling on each grid. This method involves multiplicative scaling of precipitation 
and additive offsets for temperature. The WorldClim data was used to spatially disaggregate to 30 arcsecond resolution (1 $\mathrm{km}$ resolution).

The downscaled simulation data is then validated by comparing with Global Historical Climatology Network (GHCN) station records. Two measures have been estimated to analyze the error, namely bias and Mean Absolute Error (MAE). The formulae for bias and MAE are given below:

Bias $=\frac{1}{\mathrm{n}} \sum_{\mathrm{i}=0}^{\mathrm{n}}\left(\mathrm{P}_{\mathrm{i}}-\mathrm{O}_{\mathrm{i}}\right)$,

MAE $=\frac{1}{n} \sum_{i=0}^{n}\left|\left(P_{i}-O_{i}\right)\right|$

where $P_{i}$ is the downscaled value, $\mathrm{O}_{\mathrm{i}}$ is the GHCN value, and $\mathrm{n}$ is the number of data points being compared.

\subsubsection{Delta Downscaling Method}

The bias-corrected data are used as inputs to delta method. In this method, deltas are computed at each grid cell between future and historic GCM simulations for each corresponding month. For precipitation, deltas are computed in divisions, and for temperature, deltas are computed in subtraction. Then, monthly delta grids are interpolated from GCM spatial resolution to Worldclim spatial resolution by Piecewise cubic Hermite Polynomial Interpolation method. As noted above, the interpolated deltas are applied to Worldclim dataset by using additive perturbation for temperature, and multiplicative perturbations for precipitation to produce the downscaled data.

\subsubsection{Uncertainty Analysis}

The mean change in precipitation and temperature have been calculated by the following equations:

Mean change $($ Precip $)=$

$\frac{\text { Projection MMM-Historic MMM }}{\text { Historic MMM }} \times 100$

Mean Change $($ Temp $)=$ Projection MMM - Historic MMM

where MMM represents multi-model mean.

The uncertainty between the models has been calculated by the following equation:

Mehran University Research Journal of Engineering and Technology, Vol. 40, No. 1, January 2021 [p-ISSN: 0254-7821, e-ISSN: 2413-7219]
Uncertainty $($ Precip $)=100 \times($ Projection SD /

Historic MMM)

Uncertainty $($ Temp $)=$ Projection SD

where SD is standard deviation between models' output.

In the Figs. 4 and 7, the grid cells are set to gray in cases where

|Uncertainty| > |Mean Change|

\section{RESULTS AND DISCUSSION}

\subsection{Downscaled Gridded Historical Datasets and Validation}

The diverse historical climate of the IRB and Pakistan is evident in Fig. 2. Precipitation is highest, exceeding $100 \mathrm{~mm}$, at the transition between the lowlands and HKHK Mountains. In addition, low plains (Sindh, Punjab, southern Balochistan and some parts of KPK) have high temperatures exceeding $20^{\circ}$, whereas the UIB has low temperatures below $0^{\circ} \mathrm{C}$.

The downscaled historical data were validated by comparing them with Global Historical Climatology Network (GHCN) station records. There are 183 GHCN stations with data in the study area for precipitation and 67 for temperature (Fig. 3). Bias and MAE were calculated between the downscaled and station records. The Pearson Product-Moment Correlation ' $r$ ' values for CRU and GPCC data are $0.98(p<0.05)$ and $0.94(p<0.05)$ respectively. Thus, the downscaled data are highly significantly correlated with the GHCN stations records (Table 2). The aggregated monthly bias and MAE values for downscaled GPCC precipitation data were estimated to be $26.7 \mathrm{~mm}$ and $42.5 \mathrm{~mm}$ respectively. The aggregated monthly bias and MAE values for downscaled CRU temperature data were estimated to be $0.98^{\circ} \mathrm{C}$ and $2.4^{\circ} \mathrm{C}$, respectively.

To quantify the precipitation bias in the models, the INM-CM4 model is found to be better having lowest average monthly bias of $5.4 \mathrm{~mm}$ among all models. However, BCC-CSM1-1 has highest monthly average 
bias of $15.03 \mathrm{~mm}$. To quantify the temperature bias, INM-CM4 model has highest bias of $2.37^{\circ} \mathrm{C}$; whereas,

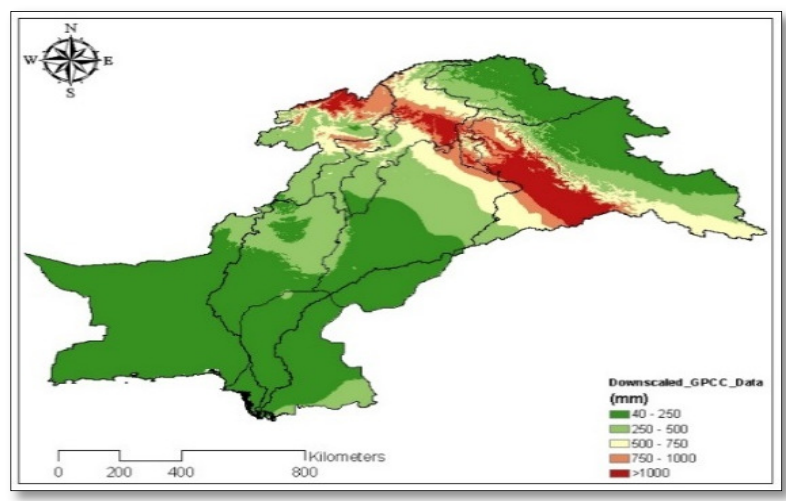

ACCESS1.3 model has lowest monthly average bias of $0.01^{\circ} \mathrm{C}$.

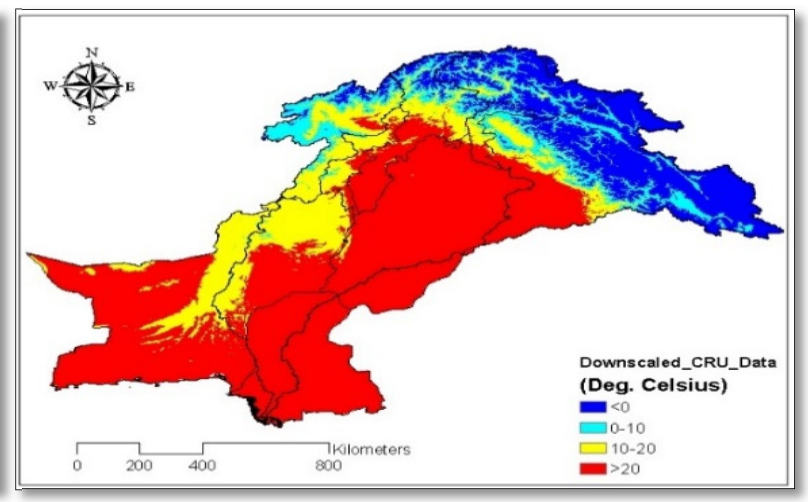

Fig. 2: Downscaled GPCC Gridded Precipitation (Left) and CRU Gridded Temperature (Right) Observations for 1960-1990

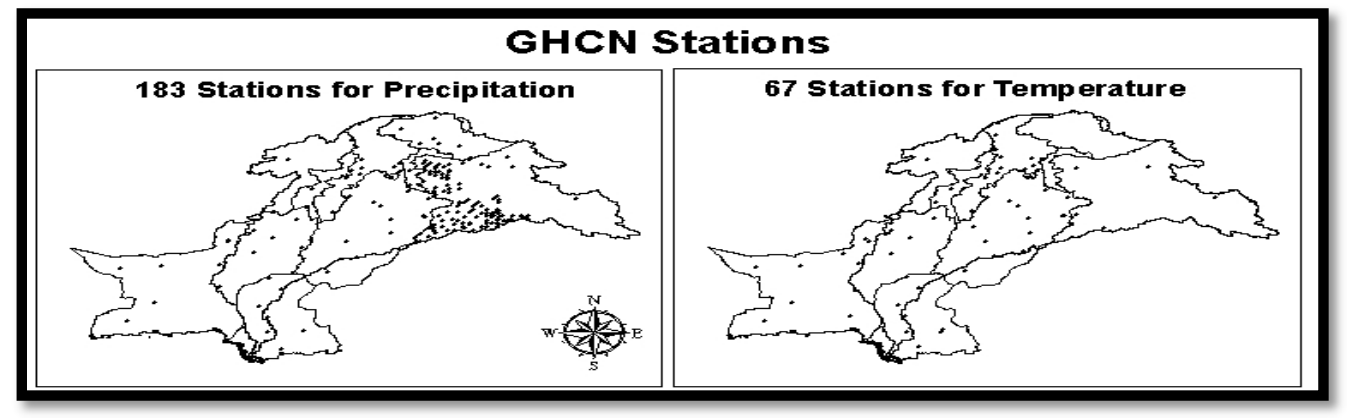

Fig. 3: GHCN Stations reporting precipitation (Left) and temperature (Right) in the Indus River Basin

\begin{tabular}{|c|c|c|}
\hline \multicolumn{3}{|c|}{$\begin{array}{c}\text { Table 2: Evaluation statistics of the downscaled } \\
\text { temperature (CRU) and precipitation data } \\
\text { (GPCC) relative to GHCN Stations. }\end{array}$} \\
\hline & CRU & GPCC \\
\hline $\begin{array}{c}\text { Average monthly } \\
\text { Bias }\end{array}$ & $0.98^{\circ} \mathrm{C}$ & $26.7 \mathrm{~mm}$ \\
\hline $\begin{array}{c}\text { Average monthly } \\
\text { MAE }\end{array}$ & $2.4^{\circ} \mathrm{C}$ & $42.5 \mathrm{~mm}$ \\
\hline $\mathrm{r}$ & 0.98 & 0.94 \\
\hline
\end{tabular}

\subsection{Projected Temperature Changes}

The changes in spatial patterns of annual mean temperature for the future period relative to the baseline period are shown in the Fig.4. The projected changes in temperature exceed uncertainty almost everywhere over the Indus Basin and Pakistan. It can be observed that the annual mean temperature has a consistent increasing trend throughout the basin. In the UIB, the mean temperature is projected to increase by 2 to $3^{\circ} \mathrm{C}$ under both RCP 4.5 and RCP 8.5 except in the eastern parts of the UIB (SW Tibetan Plateau - where the Indus River originates), where the mean temperature is projected to rise by more than $3^{\circ} \mathrm{C}$ under RCP 8.5. In Punjab province, the mean temperature is projected to increase by 1 to $2^{\circ} \mathrm{C}$ under RCP 4.5 and 2 to $3^{\circ} \mathrm{C}$ under RCP 8.5. In Sindh province, the lowest portion of the Indus Basin, the mean temperature is projected to increase by 1 to $2^{\circ} \mathrm{C}$ under RCP 4.5 and 2 to $3^{\circ} \mathrm{C}$ under RCP 8.5. In the northern and western parts of Baluchistan province, the mean temperature is projected to incline by 2 to $3^{\circ} \mathrm{C}$ under RCP 4.5 and more than $3^{\circ} \mathrm{C}$ under RCP 8.5. Whereas, in southern and eastern parts of Baluchistan province, the mean temperature is projected to rise by 1 to $2^{\circ} \mathrm{C}$ under RCP 4.5 and 2 to $3^{\circ} \mathrm{C}$ under RCP 8.5.

The uncertainty between ensemble projections estimated in Fig.5 shows that the uncertainty in projecting temperature changes under RCP 4.5 is low in most of the IRB except north-west parts and some eastern parts (SW Tibetan Plateau) where the uncertainty is comparatively higher. Similarly, under 
RCP8.5, the uncertainty in the middle belt of the IRB (Sindh, Punjab and middle belt of UIB) is low except western parts and some eastern parts where the uncertainty is comparatively higher.

The changes in spatial patterns of seasonal mean temperature for the future period relative to the baseline period are shown in the Fig.6. The models are certain that temperature will increase in the entire study area, therefore, no grey cells appear in Fig. 6. The winter (DJF) temperature in the IRB is projected to increase by $2.1^{\circ} \mathrm{C}$ under $\mathrm{RCP} 4.5$ and $2.7^{\circ} \mathrm{C}$ under $\mathrm{RCP} 8.5$. Slightly smaller increases are projected for summer (JJAS), namely $1.9^{\circ} \mathrm{C}$ under RCP4.5 and $2.5^{\circ} \mathrm{C}$ under RCP8.5. Likewise, the autumn (ON) temperature is also projected to increase by $2^{\circ} \mathrm{C}$ under $\mathrm{RCP} 4.5$ and $2.5^{\circ} \mathrm{C}$ under RCP8.5. The spring (MAM) temperature in the IRB is projected to increase by $2.1^{\circ} \mathrm{C}$ under $\mathrm{RCP} 4.5$ and $2.8^{\circ} \mathrm{C}$ under RCP8.5. Considering all of Pakistan, temperature may increase by $2.3^{\circ} \mathrm{C}$ under $\mathrm{RCP} 4.5$ and $2.9^{\circ} \mathrm{C}$ under RCP8.5 scenario. Similarly, the summer temperature is projected to increase by $2^{\circ} \mathrm{C}$ under RCP4.5 and $2.7^{\circ} \mathrm{C}$ under the RCP8.5 scenario. A more modest summer temperature increase is projected in Sindh and Punjab Provinces under the RCP4.5 scenario.
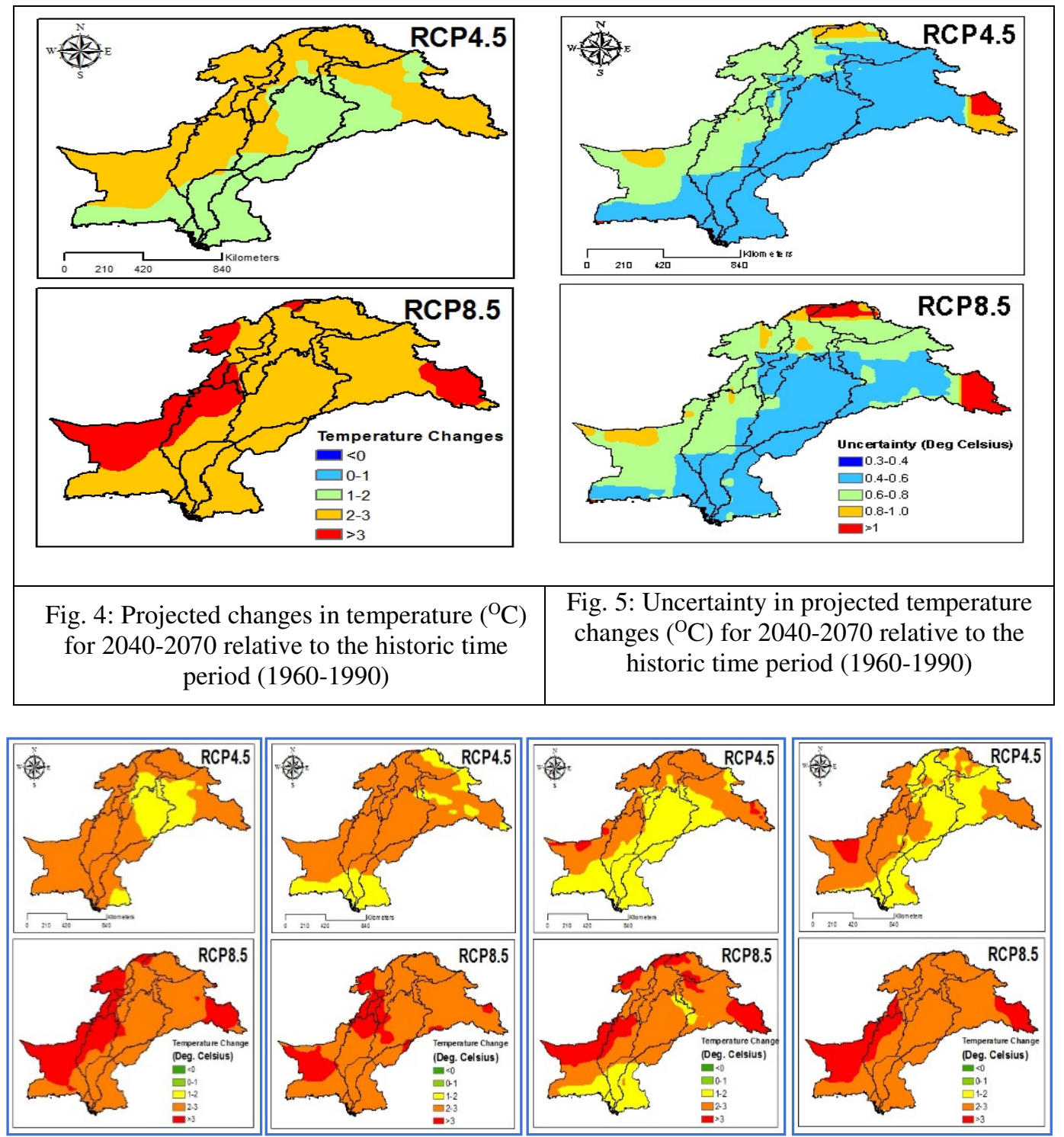

Fig 6: Projected changes $\left({ }^{\circ} \mathrm{C}\right)$ in temperature for 2040-2070 relative to the Historic Time Period (1960-1990). From Left to Right the figure represents Winter, Spring, Summer and Autumn Seasons 


\subsection{Projected Precipitation Changes}

The projected changes of the annual mean precipitation relative to the baseline period (19601990) are shown in the Fig.7. The gray grid cells specify the locations where the absolute uncertainty between ensemble projections is greater than the projected changes. It shows that there is low confidence in how precipitation will change over most the region. The results show that for all seasons and most of the Indus Basin, future precipitation is highly uncertain. However, the climate models are confident that precipitation will increase up to $20-40 \%$ in some parts of Sindh province and Gilgit under RCP 8.5. Further, the annual precipitation in eastern parts of UIB is expected to increase up to $40 \%$ under RCP 4.5 , and $60 \%$ under RCP 8.5. The UIB has a great significance regarding hydrological features and hosts thousands of glaciers and high peaks. Therefore, precipitation and temperature changes will be of great impact on the flow of the Indus River. The results show that the mean annual precipitation over the UIB is projected to increase by $8 \%$ under RCP 4.5 and $14 \%$ under RCP 8.5.
The uncertainty in projected precipitation changes relative to the historic time period is presented in fig. 8. The higher uncertainty, ranging from 30 to $40 \%$ is expected in lower Indus basin, coastal line and extreme northern areas of the IRB under both scenarios. In addition, in some of the southern parts of the IRB, the uncertainty level rises above $40 \%$ under both RCPs; whereas, in western parts of the Pakistan and middle Indus basin the uncertainty level ranges from $10-30 \%$ under both RCPs.

The changes of spatial patterns of seasonal precipitation changes for the future period relative to the baseline period are shown in the fig.9. It also shows that the precipitation will be highly uncertain in the future for most of the Indus Basin and Pakistan. However, in the winter and autumn seasons, the models are confident about change in the precipitation patterns over the UIB region. Winter precipitation over the UIB will slightly increase by $3 \%$ under RCP 4.5 and $8 \%$ under RCP 8.5. In addition, higher precipitation is projected in the autumn season as compared to other seasons. The models project precipitation increases exceeding $60 \%$ in southern parts of the IRB and Pakistan under both scenarios.
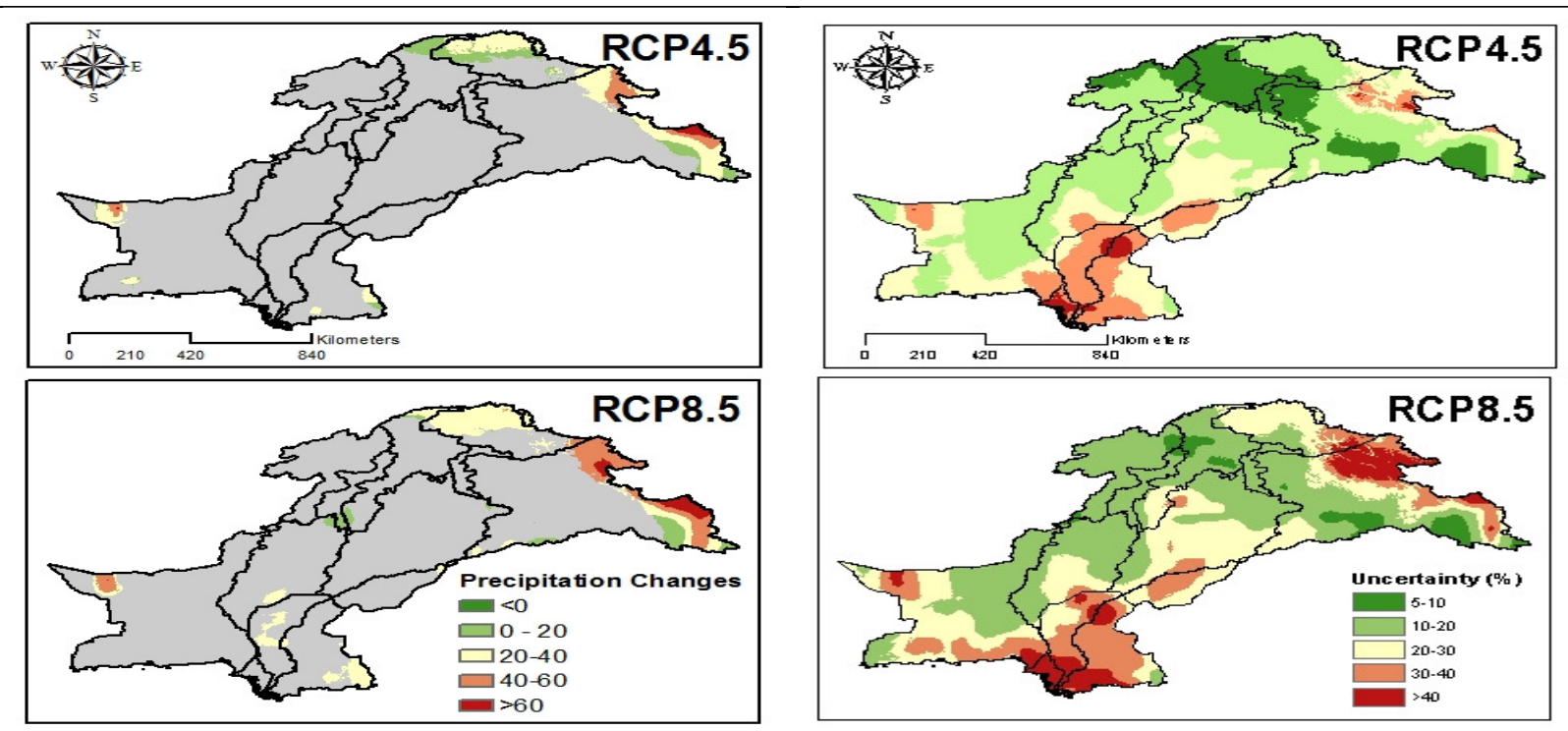

Fig. 7: Projected changes in precipitation $(\%)$ for 20402070 relative to the historic time period (1960-1990). Gray grid cells specify the locations where the absolute Fig. 8: Uncertainty in projected precipitation changes (\%) for 2040-2070 relative to the historic time period (1960-1990) uncertainty between ensemble projections is greater than the projected changes 


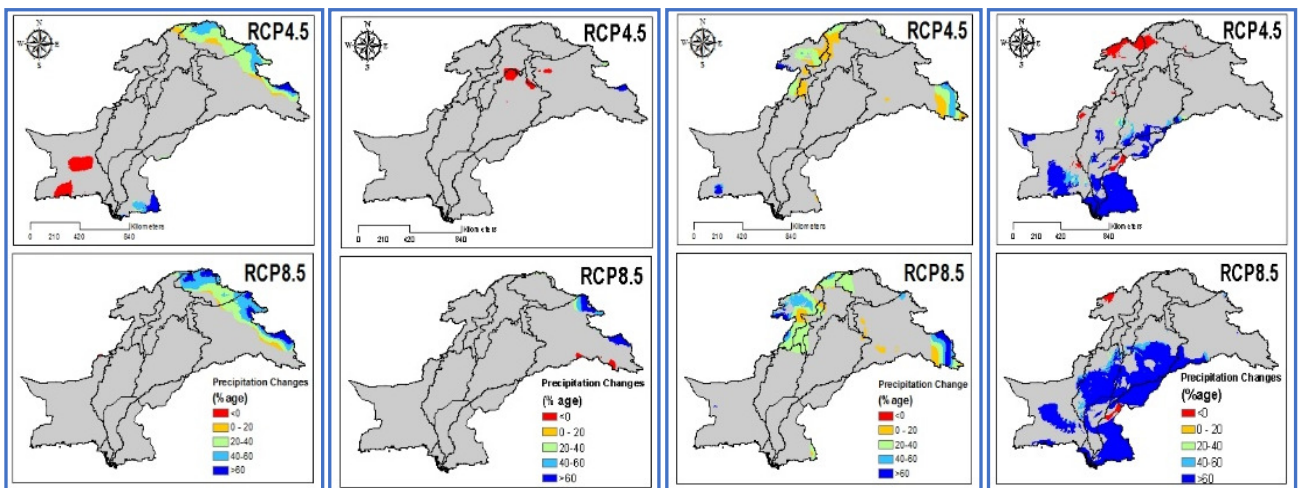

Fig. 9: Projected changes (in percentages) in precipitation for 2040-2070 relative to the historic time period (19601990). From left to right the figure represents the Winter, Spring, Summer and Autumn seasons. Gray grid cells indicate locations where the absolute uncertainty between ensemble projections is greater than the projected changes

\section{CONCLUSION}

Water resources managers and policy-makers need reliable projections of hydro-climatic conditions to develop sound water management policies. In this study, precipitation and mean temperature simulations from an ensemble of $10 \mathrm{GCMs}$ that participated in the Coupled Model Intercomparison Project Phase-5 (CMIP5) under two Representative Concentration Pathways - RCP4.5 and RCP8.5 were downscaled to a 30 arc second spatial resolution (approximately $1 \mathrm{~km}$ ) through bias correcting the simulations using quantile mapping and downscaling them with the delta method over Indus River Basin and Pakistan for 2040-2070.

Many of the previous studies such as $[9,12]$ focus on projecting climate variables but they do not explore how certain the projections are. This study has explored both long-term average changes and the uncertainty of the projections. This study finds that temperature changes are much more certain than precipitation. The projected changes in temperature are confident almost everywhere over the Indus Basin and Pakistan which is consistent with $[7,8]$. Relative to the baseline period (1960-1990), the annual mean temperature in the IRB is projected to increase by $2^{\circ} \mathrm{C}$ under RCP 4.5 and $2.6^{\circ} \mathrm{C}$ under RCP 8.5. The changes are projected to be the largest during the summer season in the UIB and North West parts of Balochistan under both scenarios. However, projected changes in precipitation are highly uncertain, indicating that GCMs are not confident whether precipitation will increase or decrease over the region in the future. However, the climate models are confident that precipitation will increase in some areas of the UIB. The GCMs are also confident that the precipitation will increase in the lower Indus Basin (most of the areas of Sindh and Punjab) in the autumn season under RCP8.5. Computational resources limited this study to 10 GCMs. Studying the full set of models in the future would provide a more robust estimate of the ensemble statistics, but this 10-GCM subset suggests large uncertainty exists across the ensemble for precipitation.

The potential changes in the precipitation and temperature are likely to affect the hydrological cycle, with serious implications on water resources and extreme events. In the UIB where both precipitation and temperature are consistently increasing, this could cause glaciers to retreat at a faster rate and cause flooding in the downstream of the Indus Basin at the initial level, but in the long term, the glaciers could melt away with serious implications for the Indus River. In the lower Indus Basin, where precipitation is highly uncertain and the temperature will significantly increase (as indicated in the results section), a major impact on the hydrologic cycle would be increasing evapotranspiration due to large irrigated agriculture, which would put immense pressure on already limited water resources [35]. These changes in climate could also affect the sowing of crops and timing of harvest in this region. Therefore, policy makers and water managers need to incorporate consideration of climate change projections in their 
future policies, and emphasize climate adaptation strategies such as water-saving technologies and climate-resilient crops.

\section{LIMITATIONS OF THE STUDY}

This study has provided some useful information about climate projections of precipitation and temperature over the IRB and Pakistan. However, it has some limitation as well. First, we used 10 GCMs due to available computational resources but addition of more models will provide reliable projections, and help the researchers in quantifying uncertainty or errors more in detail. In addition, GCMs cannot capture orographic precipitation which emphasizes upon using dynamical downscaling models in the complex terrains to provide more physically based outcomes for orographic precipitation and to explore the extent to which future climate change may depart from the historically derived empirical relationships utilized in statistical downscaling. This may be particularly informative where uncertainty in precipitation is higher, specifically southern parts and extreme northern areas of the region. Lastly, the multi-model ensemble methods such as Bayesian Model Averaging (BMA) may be used to quantify uncertainty in the models and get reliable future predictions. Therefore, future studies are encouraged to incorporate one or all of the above recommendations, based on the available resources, to improve the future projections and reduce the uncertainty of the models.

\section{ACKNOWLEDGMENTS}

Authors would like to acknowledge financial support for this study from the US-Pakistan Center for Advanced Studies in Water (USPCAS-W), Mehran UET Jamshoro, established with the grant of United States Agency for International Development (USAID). The contents are the sole responsibility of the authors and do not necessarily reflect the views of USPCAS-W, USAID or the United States or Government of Pakistan. We acknowledge the World Climate Research Program's Working Group on Coupled Modelling, which is responsible for CMIP, and we thank the climate modeling groups (listed in Table 01) for producing and making available their model output. For CMIP the U.S. Department of Energy's Program for Climate Model Diagnosis and Inter-comparison provides coordinating support and led the development of software infrastructure in partnership with the Global Organization for Earth System Science Portals.

\section{REFERENCES}

[1] Eckstein D., Künzel V., and Schäfer L., "Global Climate Risk Index 2018: Who suffers most from Extreme weather events? Weather-related loss events in 2016 and 1997 to 2016.", Germanwatch e.V., Bonn, Germany, 2017.

[2] Najafi M.R., Moazami S., "Trends in total precipitation and magnitude-frequency of extreme precipitation in Iran, 1969-2009", International Journal of Climatology, Vol. 36, No. 4, pp. 1863-1872, 2016.

[3] Dars G.H., Najafi M.R., Qureshi A.L., "Assessing the Impacts of Climate Change on Future Precipitation Trends Based on Downscaled CMIP5 Simulations Data", Mehran University Research Journal of Engineering and Technology, Vol. 36, No. 2, pp. 385-394, 2017.

[4] Chaudhry Q.U.Z., “Climate Change Profile of Pakistan", Asian Development Bank, 2017.

[5] Sheikh M.M., Manzoor N., Adnan M., Ashraf J., and Khan A.M., "Climate Profile and Past Climate Changes in Pakistan", Global Change Studies Centre, Islamabad, 2009.

[6] Fowler H.J., Archer D.R., "Conflicting signals of climatic change in the upper Indus Basin”, Journal of Climate, Vol. 19, No. 17, pp. 4276-4293, 2006.

[7] Amin A., Nasim W., Mubeen M., Sarwar S., Urich P., Ahmad A., Wajid A., Khaliq T., Rasul F., Hammad H.M., Rehmani, M.I.A., "Regional climate assessment of precipitation and temperature in Southern Punjab (Pakistan) using SimCLIM climate model for different temporal scales", Theoretical and Applied Climatology, Vol. 131, No. 1-2, pp. 121-131, 2018. 
[8] Saeed F., Athar H., “Assessment of simulated and projected climate change in Pakistan using IPCC AR4-based AOGCMs", Theoretical and Applied Climatology, Vol. 134, No. 3-4, pp. 967 - 980, 2018.

[9] Su, B., Huang, J., Gemmer, M., Jian, D., Tao, H., Jiang, T. and Zhao, C., "Statistical downscaling of CMIP5 multi-model ensemble for projected changes of climate in the Indus River Basin", Atmospheric Research, Vol. 178, pp. 138-149, 2016.

[10] Kazmi D.H., Li J., Rasul G., Tong J., Ali G., Cheema S.B., Liu L., Gemmer, M. and Fischer, T., "Statistical downscaling and future scenario generation of temperatures for Pakistan Region", Theoretical and Applied Climatology, Vol. 120, No. 1-2, pp. 341-350, 2015.

[11] Mahmood R., Babel M.S., "Evaluation of SDSM developed by annual and monthly sub-models for downscaling temperature and precipitation in the Jhelum basin, Pakistan and India", Theoretical and Applied Climatology, Vol. 113, No. 1-2, pp.27-44, 2013.

[12] Farooqi A.B., Khan A.H. and Mir, H., "Climate change perspective in Pakistan", Pakistan Journal of Meteorology, Vol. 2, No. 3, pp. 11-21, 2005.

[13] Mosier T.M., Hill D.F. and Sharp K.V., "Update to the Global Climate Data package: analysis of empirical bias correction methods in the context of producing very high resolution climate projections", International Journal of Climatology, Vol. 38, No. 2, pp.825-840, 2018.

[14] FAO, "Indus river basin", AQUASTAT Main Database, Food and Agriculture Organization of the United Nations, 2011.

[15] Qureshi A.S., McCornick P.G., Sarwar A., Sharma B.R., "Challenges and prospects of sustainable groundwater management in the Indus Basin, Pakistan", Water Resources Management, Vol. 24, No. 8, pp.1551-1569, 2010.

[16] Becker A., Finger P., Meyer-Christoffer A., Rudolf B., Schamm K., Schneider U., Ziese M., "A description of the global land-surface precipitation data products of the Global Precipitation Climatology Centre with sample applications including centennial (trend) analysis from 1901-present", Earth System Science Data, Vol. 5, No. 1, pp. 7199, 2013.

[17] Harris I.P.D.J., Jones P.D., Osborn T.J., Lister D.H., "Updated high-resolution grids of monthly climatic observations-the CRU TS3. 10 Dataset", International Journal of Climatology, Vol. 34, No. 3, pp.623-642, 2014.

[18] Peterson T.C., Vose R.S., "An overview of the Global Historical Climatology Network temperature database", Bulletin of the American Meteorological Society, Vol. 78, No. 12, pp. 2837-2850, 1997.

[19] Lawrimore J.H., Menne M.J., Gleason B.E., Williams C.N., Wuertz D.B., Vose R.S., Rennie J., "An overview of the Global Historical Climatology Network monthly mean temperature data set, version 3", Journal of Geophysical Research: Atmospheres, Vol. 116, No. D19, pp. 1-18, 2011.

[20] Hijmans R.J., Cameron S.E., Parra J.L., Jones P.G., Jarvis A., "Very high resolution interpolated climate surfaces for global land areas", International journal of Climatology, Vol. 25, No. 15, pp.1965-1978, 2005.

[21] Taylor K.E., Stouffer R.J., Meehl G.A., “An overview of CMIP5 and the experiment design", Bulletin of the American Meteorological Society, Vol. 93, No. 4, pp.485-498, 2012.

[22] Gent P.R., Danabasoglu G., Donner L.J., Holland M.M., Hunke E.C., Jayne S.R., Lawrence D.M., Neale R.B., Rasch P.J., Vertenstein M., Worley P.H., "The community climate system model version 4", Journal of Climate, Vol. 24, No. 19, pp.4973-4991, 2011.

[23] Hurrell J.W., Holland M.M., Gent P.R., Ghan S., Kay J.E., Kushner P.J., Lamarque J.F., Large W.G., Lawrence D., Lindsay K., Lipscomb W.H., "The community earth system model: a framework for collaborative 
research", Bulletin of the American Meteorological Society, Vol. 94, No. 9, pp.1339-1360, 2013.

[24] Watanabe S., Hajima T., Sudo K., Nagashima T., Takemura T., Okajima H., Nozawa T., Kawase H., Abe M., Yokohata T., Ise T., "MIROC-ESM 2010: Model description and basic results of CMIP520c3m experiments", Geoscientific Model Development, Vol. 4, No. 4, pp. 845, 2011.

[25] Bi D., Dix M., Marsland S.J., O'Farrell S., Rashid H., Uotila P., Hirst A., Kowalczyk E., Golebiewski M., Sullivan A., Yan H., "The ACCESS coupled model: description, control climate and evaluation", Australian Meteorological and Oceanographic Journal, Vol. 63, No. 1, pp.41-64, 2013.

[26] Volodin E.M., Dianskii N.A., Gusev A.V., "Simulating present-day climate with the INMCM4. 0 coupled model of the atmospheric and oceanic general circulations', Izvestiya, Atmospheric and Oceanic Physics, Vol. 46, No. 4, pp.414-431, 2010.

[27] Rotstayn L.D., Jeffrey S.J., Collier M.A., Dravitzki S.M., Hirst A.C., Syktus J.I., Wong K.K., "Aerosol-and greenhouse gas-induced changes in summer rainfall and circulation in the Australasian region: a study using singleforcing climate simulations", Atmospheric Chemistry and Physics, Vol. 12, No. 14, pp.6377-6404, 2012.

[28] Giorgetta M.A., Jungclaus J., Reick C.H., Legutke S., Bader J., Böttinger M., Brovkin V., Crueger T., Esch M., Fieg K., Glushak K., "Climate and carbon cycle changes from 1850 to 2100 in MPI-ESM simulations for the Coupled Model Intercomparison Project phase 5", Journal of Advances in Modeling Earth Systems, Vol. 5, No. 3, pp.572-597, 2013.

[29] Delworth T.L., Broccoli A.J., Rosati A., Stouffer R.J., Balaji V., Beesley J.A., Cooke W.F., Dixon K.W., Dunne J., Dunne K.A.,
Durachta J.W., “GFDL's CM2 global coupled climate models. Part I: Formulation and simulation characteristics", Journal of Climate, Vol. 19, No. 5, pp.643-674, 2006.

[30] Wu T., Yu R., Zhang F., Wang Z., Dong M., Wang L., Jin X., Chen D., Li L., "The Beijing Climate Center atmospheric general circulation model: description and its performance for the present-day climate", Climate Dynamics, Vol. 34, No. 1, pp.123, 2010.

[31] Arora V.K., Scinocca J.F., Boer G.J., Christian J.R., Denman K.L., Flato G.M., Kharin V.V., Lee W.G., Merryfield W.J., "Carbon emission limits required to satisfy future representative concentration pathways of greenhouse gases", Geophysical Research Letters, Vol. 38, No. 5, pp. 3-8, 2011.

[32] Fekete B.M., Vörösmarty C.J., Roads J.O., Willmott C.J., "Uncertainties in precipitation and their impacts on runoff estimates", Journal of Climate, Vol. 17, No. 2, pp.294304, 2004.

[33] Piani C., Weedon G.P., Best M., Gomes S.M., Viterbo P., Hagemann S., Haerter, J.O., "Statistical bias correction of global simulated daily precipitation and temperature for the application of hydrological models", Journal of Hydrology, Vol. 395, No. 3-4, pp.199-215, 2010.

[34] Theme B1 M.J., Gobiet A., Heinrich G., "Empirical-statistical downscaling and error correction of regional climate models and its impact on the climate change signal", Climatic Change, Vol. 112, No. 2, pp.449468, 2012.

[35] Ahmad W., Fatima A., Awan U.K., Anwar A., "Analysis of long term meteorological trends in the middle and lower Indus Basin of Pakistan-A non-parametric statistical approach", Global and Planetary Change, Vol. 122, pp.282-291, 2014. 